\title{
WITHIN-SEASON NEST REUSE BY MOUNTAIN PLOVERS (CHARADRIUS MONTANUS) IN EASTERN COLORADO
}

\author{
Lani T. Stinson ${ }^{1}$ and Victoria J. Dreitz ${ }^{1,2}$
}

\begin{abstract}
AвstRaCT.-The Mountain Plover (Charadrius montanus) is a declining migratory shorebird that nests on shortgrass prairies across the western Great Plains. This ground-nesting species exhibits an uncommon split-clutch mating system, in which each member of a pair simultaneously incubates a nest and uniparental care continues throughout brood-rearing. We report on an observation of within-season nest reuse in this species. To our knowledge, this report includes the first documented occurrence of 2 different Mountain Plovers using the same nest cup in the same breeding season. Nest reuse could represent a time- and energy-saving strategy for renesting individuals.
\end{abstract}

RESUMEN.-El chorlo llanero (Charadrius montanus) es una ave playera migratoria en las praderas de pastos cortos en las Grandes Llanuras occidentales. Esta especie anida en el suelo, y presenta un sistema de división de puesta poco común, en la que cada individuo de un par incuba un nido al mismo tiempo y este cuidado uniparental continúa durante todo el periodo de atender las crías. Aquí reportamos una observación del comportamiento de la reutilización de nidos dentro del mismo año para esta especie. Según nuestro leal saber y entender, esta es la primera ocurrencia documentada de dos chorlos llaneros diferentes que utilizan el mismo nido en la misma temporada de crianza. Reutilización de los nidos puede representar una estrategia para ahorrar tiempo y energía para esta especie.

The Mountain Plover (Charadrius montanus) is a migratory upland shorebird that has experienced population declines throughout its range over the last 4 decades (Knopf and Wunder 2006). This medium-sized $(\sim 100$ g), drab-colored shorebird breeds primarily in shortgrass prairie habitats throughout the western Great Plains states, with more than 50\% of the North American population breeding in the prairies of eastern Colorado (Kuenning and Kingery 1998, Knopf and Wunder 2006). Mountain Plover nesting habitat is generally characterized by flat areas with sparse vegetation and bare ground, including grazed native grasslands and agricultural lands (Graul 1975, Olson and Edge 1985, Knopf and Miller 1994, Dreitz and Knopf 2007).

The Mountain Plover arrives on its breeding grounds in eastern Colorado in early March and stays until late July or early August (Knopf and Wunder 2006). Shortly after arrival, males begin establishing territories and displaying for breeding females at multiple nest-scrape locations. Egg-laying typically begins by mid- to late April and extends into mid-June (Graul 1975, Knopf and Wunder 2006). The Mountain Plover exhibits a unique mating system in which the female lays two 3-egg clutches in rapid succession; the first clutch is laid in a nest to be incubated by the male, and the second is tended solely by the female (Graul 1973, 1976). Incubation periods normally range from 28 to 31 days, with uniparental care continuing during brood-rearing and chicks fledging 30-36 days post-hatch (Graul 1975, Miller and Knopf 1993). In eastern Colorado, the length of the nesting season is highly variable and weather dependent, but nesting generally lasts into late July, with eggs observed hatching as late as 21 July in some years (V.J. Dreitz unpublished data). If the eggs or chicks from the initial nesting attempt are lost early in the breeding season, it is possible for a plover to successfully hatch chicks from a replacement nest (Graul 1975, Knopf and Wunder 2006, Skrade and Dinsmore 2010).

We monitored Mountain Plover nests and chicks from April through July on private lands covering approximately $2100 \mathrm{~km}^{2}$ in Lincoln County, Colorado. After 11 years of research on Mountain Plover reproductive biology in eastern Colorado (i.e., 2001-2012), we have observed a unique renesting event in a nest cup previously used by another plover. To our knowledge, this is the first documented occurrence of use of the same nest cup by 2

\footnotetext{
${ }^{1}$ Colorado Parks and Wildlife, 317 West Prospect Road, Fort Collins, CO 80526.

${ }^{2}$ Corresponding author. Present address: University of Montana, Wildlife Biology Program and Avian Science Center, College of Forestry and Conservation, Missoula, MT 59812.E-mail: victoria.dreitz@cfc.umt.edu
} 
different Mountain Plovers in the same breeding season.

On 21 April 2011, we located a Mountain Plover nest in the laying stage on grassland occupied by black-tailed prairie dogs (Cynomys ludovicianus). Using egg flotation (Westerskov 1950), we monitored stage of incubation until hatching. We also placed a small weather data logger (Thermochron iButton, Embedded Data Systems, Lawrenceburg, KY) at the bottom of the nest, following field protocols similar to Hartman and Oring (2006). We later captured, banded (Band \#1232-11228, hereafter Plover \#28), and attached a radiotransmitter to the tending adult. We continued monitoring the nest until 21 May, when 2 chicks hatched (the third egg had disappeared midway through incubation). As part of a longterm study, we located the 2 chicks every 24 $48 \mathrm{~h}$ and determined their survival status; neither chick survived to fledge (chicks died before reaching 30 days old).

Approximately 17 days later, on 7 June, 3 eggs were found in the exact location (based on location coordinates) as Plover \#28's nest; however, the nest was being incubated by a different adult (Band \#1232-11146, hereafter Plover \#46). A nail that had been used to anchor the iButton to the bottom of Plover \#28's nest (Hartman and Oring 2006) was still present in the nest when it was found occupied by Plover \#46, providing further evidence of the nest reuse. Not only were the eggs of Plover \#46 in a previously used cup, but they also constituted a "replacement" nest, initiated less than 18 days after the loss of Plover \#46's first clutch. We should note, however, that without knowing the sex of the 2 individuals, we are unable to rule out the possibility that Plover \#46 was mated to Plover \#28.

Plover \#46 had begun incubating its first clutch early in the breeding season in similar habitat (prairie dog colony) approximately 430 $\mathrm{m}$ from the site of the replacement nest. We located Plover \#46's first nest on 21 April and continued monitoring it until 19 May, when one chick hatched. The following day, we located the chick dead in a burrow $48 \mathrm{~m}$ from the nest. When found on 7 June, Plover \#46's second nest (i.e., replacement nest) was at early-incubation stage, with approximately 2.5- 3 weeks left until hatching. On 21 June, Plover \#46's second nest was deemed failed due to abandonment, based on eggs found cold, dirty, not progressing in incubation stage, and displaced from the nest cup. When we dissected the eggs from the failed nest, we found no evidence of embryonic development, indicating that either the eggs were infertile or the nest was abandoned prior to the onset of incubation.

Many species of shorebirds lay replacement clutches following the loss of their nest or brood from predation or other causes. These species include members of the family Charadriidae, such as the Kentish Plover (Charadrius alexandrinus; Amat et al. 1999a), Semipalmated Plover (Charadrius semipalmatus; Flynn et al. 1999), and Malaysian Plover (Charadrius peronii; Yasué and Dearden 2008). Renesting attempts have also been reported for the Mountain Plover from studies conducted in other parts of its breeding grounds, specifically in Weld County, Colorado (Graul 1975, Knopf and Rupert 1996, Knopf and Wunder 2006), and Phillips County, Montana (Skrade and Dinsmore 2010). Few studies have reported on the timing or relative locations of initial and replacement nest sites within a single breeding season, but Skrade and Dinsmore (2010) found that $60 \%-70 \%$ of Mountain Plover renesting attempts over a 14-year period $(n=48)$ occurred on the same prairie dog colony as the initial nest.

Due to the Mountain Plover's unique mating system and ability to renest following nest failures, each plover pair has the potential for up to 4 nest attempts in a single breeding season, thus spreading out risk and increasing the possibility of nest success (Knopf and Wunder 2006). Though renesting is a viable option for some plovers that lose their eggs or broods early in the season, it may not be feasible for all individuals due to timing or energetic constraints. There is an energetic cost to reproduction; thus, renesting birds may have fewer resources to allocate to predator defense/avoidance, foraging, and maintenance of health and body condition prior to migration (Schmidt and Whelan 2010). In addition to the energy required to lay and incubate eggs, there are energetic costs associated with nest site selection and construction. Though nest-building costs are admittedly much lower for open-nesting shorebirds as compared to species that construct or excavate more elaborate nests, the use of a preconstructed nest cup may still have represented some time or 
energy savings for Plover \#46, as suggested for several other species (Amat et al. 1999b, Cavitt et al. 1999, Horn et al. 2007, Richmond et al. 2007). Though we can only speculate about the potential fitness benefits of nesting in a preconstructed, pre-used nest cup, the documentation of this behavior in the Mountain Plover is an interesting finding in the context of this declining species' potential reproductive strategies.

We thank the landowners throughout Lincoln County who allowed us access to their lands. We thank C.J. Archuleta, E.L. Birtwistle, A.H. Harrington, K.A. Kovach, W.L. Lutz, L.N. Messinger, M.M. Riordan, and N.A. Schwertner for field assistance. Financial and logistical support was provided by Colorado Parks and Wildlife.

\section{Literature Cited}

Amat, J.A., R.M. Fraga, and G.M. Arroyo. 1999a. Replacement clutches by Kentish Plovers. Condor 101: 746-751.

1999b. Reuse of nesting scrapes by Kentish Plovers. Condor 101:157-159.

CavitT, J.F., A.T. Pearse, and T.A. Miller. 1999. Brown Thrasher nest reuse: a time saving resource, protection from search-strategy predators, or cues for nestsite selection? Condor 101:859-862.

Dreitz, V.J., AND F.L. KNOPF. 2007. Mountain Plovers and the politics of research on private lands. BioScience 57:681-687.

FlynN, L., E. Nol, AND Y. Zharikov. 1999. Philopatry, nest-site tenacity, and mate fidelity of Semipalmated Plovers. Journal of Avian Biology 30:47-55.

Graul, W.D. 1973. Adaptive aspects of the Mountain Plover social system. Living Bird 12:69-94. 1975. Breeding biology of the Mountain Plover. Wilson Bulletin 87:6-31.

1976. Food fluctuations and multiple clutches of the Mountain Plover. Auk 93:166-167.
Hartman, C.A., And L.W. Oring. 2006. An inexpensive method for remotely monitoring nest activity. Journal of Field Ornithology 77:418-424.

Horn, J.A., M.P. Ward, M.G. Alessi, T.A. Danner, and R.J. NovaK. 2007. Observation of a Northern Cardinal nest reused by a Gray Catbird in the same season. Wilson Journal of Ornithology 119:761-762.

Knopf, F.L., And B.J. Miller. 1994. Charadrius montanus: montane, grassland, or bare-ground plover? Auk 111:504-506.

KNOPF, F.L., AND J.R. Rupert. 1996. Reproduction and movements of Mountain Plovers breeding in Colorado. Wilson Bulletin 108:28-35.

KNopf, F.L., AND M.B. Wunder. 2006. Mountain Plover (Charadrius montanus). The birds of North America. Number 211.

Kuenning, R.R., and H.E. Kingery. 1998. Mountain Plover. Pages 170-171 in H.E. Kingery, editor, Colorado breeding bird atlas. Colorado Bird Atlas Partnership and Colorado Division of Wildlife, Denver, CO.

Miller, B.J., AND F.L. KNOPF. 1993. Growth and survival of Mountain Plovers. Journal of Field Ornithology 64:500-506.

Olson, S.L., AND D. Edge. 1985. Nest site selection by Mountain Plovers in northcentral Montana. Journal of Range Management 38:280-282.

Richmond, S., E. Nol, M. Campbell, and D. Burke. 2007. Conspecific and interspecific nest reuse by Wood Thrush (Hylocichla mustelina). Northeastern Naturalist 14:629-636.

Schmidt, K.A., AND C.J. Whelan. 2010. Nesting in an uncertain world: information and sampling the future. Oikos 119:245-253.

Skrade, P.D.B., and S.J. Dinsmore. 2010. Sex-related dispersal in the Mountain Plover (Charadrius montanus). Auk 127:671-677.

Westerskov, K. 1950. Methods for determining the age of game bird eggs. Journal of Wildlife Management $14: 56-67$.

Yasué, M., AND P. Dearden. 2008. Replacement nesting and double-brooding in Charadrius peronii: effects of season and food availability. Ardea 96:59-72.

Received 28 March 2013 Accepted 11 October 2013 